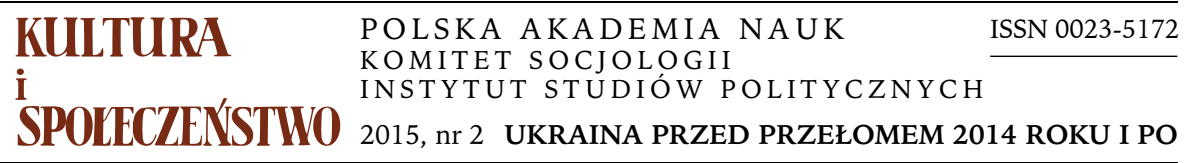

TOMASZ KIZWALTER

Uniwersytet Warszawski

\title{
UKRAINA, ROSJA I PROBLEM PERYFERYJNOŚCI
}

Czy wydarzenia na Ukrainie mają dziś jedynie lokalne znaczenie, czy też uwidacznia się w nich problematyka istotna dla innych krajów? Czy chodzi tu li tylko o specyfikę słowiańskiego Wschodu — jak skłonna jest sądzić duża część zachodnich obserwatorów - czy może o zjawiska, których wymiar jest ogólnoświatowy?

Na czym miałaby polegać - w stereotypowym ujęciu — „wschodnia specyfika" w wersji ukraińskiej? Punktem wyjścia powinny być w tym przypadku różne, mniej czy bardziej malownicze, refleksje o „duszy rosyjskiej” lub „rosyjskiej tradycji" (Veǐdle 1949; Szamuely 1974). Wokół tych pojęć skupiały się, zarówno w Rosji, jak i w innych krajach, zespoły wyobrażeń podkreślające rosyjską odmienność od Zachodu. Ideowej wyrazistości i spójności nabrały owe wyobrażenia w połowie XIX wieku, wraz z kształtowaniem się koncepcji słowianofilskich, słowianofilizm pozostał też podstawą wielu późniejszych wypowiedzi na temat specyfiki Rosji. Słowianofile przyjmowali tezę o głęboko, historycznie ugruntowanej odrębności tego, co rosyjskie, i tego, co zachodnie. Fundamentem podziału miała być różnica wyznaniowa: w katolicyzmie i protestantyzmie treści chrześcijańskie nosiły wyraźne ślady oddziaływania dziedzictwa antycznego Rzymu, w prawosławiu natomiast, jak powtarzali rosyjscy myśliciele, zachowały swą czystość. Wpływy rzymskie - w tym szczególnie przyswajanie prawa rzymskiego - zdaniem słowianofilów były zdecydowanie destrukcyjne. Podczas gdy prawosławie znamionował autentyzm wiary, chrześcijaństwo zachodnie przepajał bezduszny racjonalizm. Ponieważ religia stanowiła fundament kultury, zatem i całokształt zachodniej egzystencji cechowały

Adres do korespondencji: t.kizwalter@uw.edu.pl 
postawy racjonalistyczne, konstytutywną cechą społeczeństwa rosyjskiego zaś była, najkrócej mówiąc, szczerość i naturalność uczuć. Ludzie Zachodu żyli w sposób sztuczny, Rosjanie - naturalny i organiczny. Słowianofile tworzyli wizję idealnego, tradycjonalistycznego porządku, który przeciwstawiali niszczycielskiej nowoczesności (Walicki 1964).

Dla rosyjskiego imperium kwestia modernizacji miała pierwszorzędne znaczenie. Od czasów panowania Piotra I w życiu państwa następowały po sobie naprzemiennie okresy reform i konserwacji. Modernizacyjne poczynania władzy budziły smutek słowianofilów, którzy pocieszali się jednak, że jeszcze nie jest za późno, aby szkodliwe zmiany powstrzymać i przywrócić należyty stan rzeczy. Istotnie, reformowanie imperium $z$ jednej strony było przedsięwzięciem trudnym ze względów praktycznych, $z$ drugiej — budziło niekończące się kontrowersje w obrębie imperialnego establishmentu i elit społecznych. Mocarstwowe aspiracje i obawa przed silniejszymi państwami skłaniały do modernizacji, zniechęcały do niej niepożądane efekty reform i resentyment wobec Zachodu, czynniki ściśle łączące się ze sobą. Dla sfer rządowych i warstw wyższych niepożądany efekt stanowiło rzeczywiste lub domniemane osłabienie porządku politycznego, dla radykałów społecznych mógł to być rozwój stosunków kapitalistycznych - w obu przypadkach widziano oddziaływania zachodnie.

Pisząc teraz o znaczeniu modernizacji, nie zapominam, że od kilkudziesięciu lat pojęcie to traci na popularności. Minęly czasy, kiedy naukowcy i różnego rodzaju eksperci konstruowali nieskomplikowane i nacechowane rozwojowym optymizmem schematy ekspansji nowoczesności (Black 1976; Wehler 1975; Tipps 1973). Obecnie nowoczesność znacznie częściej jest przedmiotem krytycznych analiz, w których wskazuje się na jej złożoność, niejednoznaczność i destrukcyjny potencjał (Bauman 2009). Nie neguję przynajmniej częściowej zasadności tych krytyk, sądzę jednak, że zastanawiająca jest rozbieżność między opiniami dużej części intelektualistów a odczuciami przeważającymi, jak się wydaje, w innych środowiskach. Wiele wskazuje, że większość ludzi chciałaby tego, co na ogół (choć oczywiście nie zawsze) niesie ze sobą nowoczesność: dostatku materialnego, emancypacji społecznej, praw jednostki. Jeśli nawet mieszkańcy krajów wysoko rozwiniętych gospodarczo uważają swe położenie za coś naturalnego, to dla społeczeństw uboższych problem rozwoju ma charakter znacznie bardziej dramatyczny. Przypominanie o tym nie jest prawieniem banałów, bo nie są to wcale kwestie oczywiste, czego świadectwo mogą stanowić między innymi dzieje pojęć takich jak „centrum” i „peryferie”, traktowanych jako instrument interpretacji procesów rozwojowych.

Podział na obszar centralny i strefy peryferyjne, kluczowy dla klasycznej teorii modernizacji (Sosnowska 2004), z czasem budził coraz więcej obiekcji i jego obecny status jest dość wątpliwy. Przy różnych okazjach słyszy się, że żadnych centrów i peryferii nie ma, albo że peryferie są wszędzie, i tak dalej (zob. $\mathrm{m}$. in. Odpowiedzi na ankietę 2013). Można to $z$ jednej strony uznać za uzasadnioną reakcję na częste uproszczenia występujące przy posługiwaniu się owym 
schematem, ale $z$ drugiej strony niechęć do niego ma wyraźne podłoże pozanaukowe. Poczucie, że żyje się na peryferii, bywa przykre, czasem trudne do zniesienia; okazało się też, że przeświadczenie o własnej „centralności” może stać się krępujące. Posługiwanie się interesującymi nas teraz pojęciami zaczęto uważać - nie całkiem bezpodstawnie - za przejaw przemocy symbolicznej, narzucania dyskursu i innych kolonialnych obyczajów (Wolff 1994). Jestem jednak przekonany, że podział na centrum i peryferie to narzędzie badawcze, które - umiejętnie stosowane - będzie użyteczne przy badaniu obecnej sytuacji na Ukrainie, a także pozwoli podjąć próby studiów porównawczych.

W przypadku ukraińskim podstawy obecnego stanu rzeczy były już w miarę wyraźnie ukształtowane pod koniec XIX wieku. Państwo rosyjskie zaczynało wchodzić wtedy w okres strukturalnego kryzysu, a jeden $z$ jego istotnych aspektów stanowiła nasilająca się konfrontacja imperialnego centrum władzy z ruchami narodowymi. W następnym stuleciu konflikty takie mogły nasilać się lub ulegać stłumieniu, w zależności od warunków politycznych, lecz nie udało się ich zupełnie wygasić - w znacznej mierze dlatego, że były ściśle związane $z$ problemami modernizacyjnymi Rosji. W drugiej połowie XIX wieku władze rosyjskie podejmowały wysiłki mające na celu „unarodowienie” imperium, wprowadzając $\mathrm{w}$ życie strategie rusyfikacyjne na terenach odmiennych etnicznie (Szporluk 2003; Nowak 2011; Weeks 1996). Efekty podobnych działań pozostawały bardzo ograniczone - $\mathrm{w}$ tradycjach społeczeństw poddawanych wtedy rusyfikacji przypisywano to głównie własnej sile oporu, ale należało by $\mathrm{w}$ tym widzieć przede wszystkim efekt cywilizacyjnego zacofania imperium i słabości rosyjskich struktur państwowych. Zabiegi mające na celu budowę wspólnot narodowych były w tamtym okresie typową aktywnością państw zachodnioeuropejskich. Rosja próbowała naśladować pod tym względem Zachód, do zachodnich wzorów nawiązywali też członkowie przeciwstawiających się imperium ruchów narodowych. W obu przypadkach próbowano przezwyciężyć modernizacyjną niewydolność państwa.

Ukraiński ruch narodowy kształtował się w polu oddziaływania tradycji politycznych polsko-litewskiej Rzeczypospolitej, imperium rosyjskiego oraz monarchii habsburskiej. Każda $z$ tych tradycji w XIX wieku była związana $z$ aktywnością elit występujących jako przedstawiciele narodów, które nazywano wtedy „historycznymi”. Rozróżnianie narodów „historycznych” i „niehistorycznych” pod koniec XX wieku uznano za nieprzyzwoite, podkreślając, że każdy naród ma swoją historię. Trudno się nie zgodzić z takim twierdzeniem, ale trudno też ignorować historyczne odmienności. Omawiany podział, popularny zwłaszcza w monarchii habsburskiej, był istotnie zaprawiony poczuciem wyższości tych, którzy go stworzyli i zaliczali swoje wspólnoty do „historycznych”, lecz ma również niebagatelne walory analityczne. „Historyczność” wynikała tu z trzech kryteriów: posiadania własnego państwa lub żywotnej tradycji państwowej, rodzimych warstw wyższych i rodzimej kultury wyższej. Sto lat temu tego rodzaju stan posiadania często skłaniał do wywyższania się, nie widać jednak powodu, 
abyśmy dziś nie mogli zaakceptować tego, co stanowi użyteczne narzędzie badawcze. Dziewiętnastowieczna „historyczność”, choć występowała w otoczce arogancji, a przynajmniej protekcjonalności, odnosi się bowiem do czynników realnych, mających kluczowe znaczenie dla procesów narodowotwórczych (Chlebowczyk 1983, s. 21-23; Rosdolsky 1964; Walicki 1996, s. 150-163). Ukraińska polityka narodowa pojawiała się w XIX wieku jako aktywność pozbawiona „historycznego” zaplecza (brak ten kompensowano zwyczajowymi wówczas zabiegami mitologizującymi przeszłość), plebejska, taka, której pierwszym celem było pozyskanie uznania dla własnej podmiotowości politycznej. Pamiętajmy, że gdy „kwestia ukraińska” była uważana za rosyjski lub polski problem wewnętrzny, nigdy nie brakowało głosów, że ukraińskie aspiracje narodowe oparte są na fikcyjnych podstawach.

W wyniku drugiej wojny światowej Ukraina znalazła się całkowicie w zasięgu panowania sowiecko-rosyjskiego, co oznaczało trwałą obecność w strefie modernizacji ułomnej i połowicznej. Rozpad ZSRR i państwowe wyodrębnienie się Ukrainy zapoczątkowały okres politycznych perturbacji, który trwa do dziś. Nie wdając się $w$ analizę obecnej sytuacji politycznej, ani tym bardziej nie próbując przewidywać przyszłego biegu wydarzeń, chciałbym zastanowić nad perspektywami, jakie otwierają się przed społeczeństwem ukraińskim.

Jednym $z$ charakterystycznych rysów sowieckiej modernizacji - obok ekonomicznej niewydolności przyjmowanych strategii rozwojowych i destrukcyjności ich społecznych konsekwencji - był bardzo ograniczony zakres przemian kulturowych i mentalnych. Oczywiście, początkowo nowa władza miała pod tym względem wielkie skłonności niszczycielskie i aspiracje nowatorskie, lecz plany uformowania „nowego człowieka” okazały się iluzją. Homo sovieticus w wersji poststalinowskiej miał w sobie niewiele takich cech, które rzecznicy teorii modernizacji uznawali za nowoczesne w jej złotych latach. Dostrzec w nim można było za to osobliwie zmutowaną spuściznę pańszczyźnianego chłopa i carskiego biurokraty (Kołakowski 1988, s. 904-905).

Twierdzenie, że niedorozwój miejskiej klasy średniej jest typową słabością krajów peryferyjnych, było wielokrotnie krytykowane. Kłóci się zarówno z intelektualnymi tradycjami tych krajów - gdzie często podkreśla się modernizacyjne zasługi inteligencji (zob. m.in. Domański 2008) — jak i z popularną obecnie koncepcją „nowoczesności zwielokrotnionych” (Eisenstadt 2009). Moim zdaniem, materiał historyczny wyraźnie wskazuje, że to zachodnioeuropejskie i północnoamerykańskie mieszczaństwo stworzyło kulturowy fundament rozwojowego sukcesu Zachodu. Rezultaty sowieckich wysiłków zaś mogą być jednym $z$ argumentów na rzecz tezy, że brak mieszczańskiego podłoża poważnie ogranicza szanse modernizacyjne.

„Dusza rosyjska”, o której wspominałem na wstępie, to znamienny produkt tamtejszych konfrontacji z nowoczesnością. Można powiedzieć - rzecz jasna, upraszczając problem złożony - że ten zespół wyobrażeń wynika z kompleksu niższości wobec Zachodu i w pewien sposób kompensuje nieprzyjemne poczu- 
cie pozostawania w tyle pod względem materialnym (i nie tylko materialnym). Racjonalnej kalkulacji, którą nie tylko Weber uznawał za podstawę kultury zachodniej, przeciwstawia się w tym ujęciu rosyjską duchowość: głębokość wiary i autentyczność uczuć. Egzystencjalna prawda jest po stronie Rosjan; Zachód tylko pozornie prosperuje - $\mathrm{w}$ istocie pogrąża się $\mathrm{w}$ wyjałowionej $\mathrm{z}$ treści, bezdusznej wegetacji. Tego rodzaju mniemania nie są oczywiście niczym wyjątkowym na peryferiach: wszędzie tam, gdzie dochodzi do kontaktu z cywilizacyjną potęgą, pojawiają się odpowiednie mechanizmy kompensacyjne (Jedlicki $2002,2010)$. W przypadku rosyjskim efekty ich działania okazały się jednak nieprzeciętnie silne, głęboko zakorzeniły się w zbiorowej wyobraźni i splotły $z$ imperialnymi ambicjami.

W świetle dotychczasowych doświadczeń można śmiało powiedzieć, że obietnica prawdziwego życia, jaką dawały (i daja) antyzachodnie wyobrażenia, to wielka i tragiczna ułuda. Rosja jest tego dobitnym przykładem, chociaż od razu można wymienić bardziej drastyczne przypadki oddziaływania podobnych fobii. Nie twierdzę w żadnym razie, że krytyka Zachodu jest całkowicie bezpodstawna - niejednokrotnie miano aż nadto powodów, aby ją podejmować. Ale krytykiem Zachodu był przecież przede wszystkim sam Zachód, a to, co mówiono i pisano w innych kręgach kulturowych, najczęściej miało za inspirację tę właśnie, wewnątrzzachodnią krytykę (słowianofile byli pilnymi czytelnikami zachodnioeuropejskich autorów). Tę zdolność do autokrytyki należałoby uznać za szczególną cechę kultury zachodniej i w znacznej mierze przyczynę jej siły. U podstaw mamy tu myśl Oświecenia, tyle razy już składaną do grobu - na Zachodzie i gdzie indziej. Wieści o jej śmierci zawsze okazywały się jednak przedwczesne: historię dziewiętnasto- i dwudziestowiecznej Europy można rozpatrywać jako dzieje oświeceniowej z ducha autokrytyki, pozwalającej poprzez doświadczenia często niezwykle bolesne - posuwać się do przodu pod względem materialnego poziomu życia, emancypacji społecznej i praw jednostki. Gdyby tego rodzaju krytycyzmu zabrakło, nasz - mam na myśli nie tylko Europejczyków - los byłby żałosny (zob. Kołakowski 1990, s. 7-36; Jedlicki 2000, s. 17-82).

Nie sposób przewidywać, jak wyglądać będzie przyszłość Ukrainy. Trzeba natomiast powiedzieć, że przed społeczeństwem ukraińskim otwierają się nowe możliwości. Kształtująca się w XIX wieku ukraińska kultura narodowa, ścierająca się z polityczno-kulturowymi oddziaływaniami narodów „historycznych”, znalazła się wówczas w położeniu, które dziś często nazywa się „kolonialnym”. Określenie „kolonialny” bywa nadużywane, jest też bardzo nieprecyzyjne, nie chodzi mi więc o to, aby dzieje Ukrainy wtłaczać w ramy wyznaczane przez „dyskursy kolonialne” i „postkolonialne”. Studia postkolonialne zwracają jednak uwagę na kluczową w przypadku ukraińskim kwestię kulturowej i politycznej podmiotowości (zob. Riabczuk 2014).

Polskie dziewiętnastowieczne twierdzenie, że „Ukraińców wymyślił gubernator Stadion", to dobrze znane świadectwo niechęci, z jaką przedstawiciele 
narodu „historycznego" odnosili się do aspiracji, które w ich przekonaniu nie miały „historycznych” podstaw. Tradycja Rzeczypospolitej, w Polsce najczęściej idealizowana, nie ułatwiała pogodzenia się z ukraińskimi dążeniami emancypacyjnymi. Była wytworem szlacheckiej klasy politycznej, etnicznie polskiej lub spolonizowanej. Ten czynnik etniczny nie miał większego znaczenia przed upadkiem państwa, ale w XIX wieku stawał się coraz ważniejszy. Środowiska ziemiańsko-inteligenckie, które po rozbiorach kultywowały tradycję dawnego państwa szlacheckiego, starały się minimalizować znaczenie polityczne odmienności etnicznej. Chłopskie społeczności wschodnich ziem Rzeczypospolitej uznawano - w poczuciu społeczno-kulturowej wyższości i z dużą dozą protekcjonalności - za ludy ściśle spokrewnione z Polakami, występującymi w roli „starszych braci” (Wapiński 1994, s. 133-144). Wobec rozwoju ruchów narodowych i nacjonalizmów było to już jednak stanowisko anachroniczne, a jego skuteczne podtrzymywanie wymagało odpowiedniej dozy polityczno-militarnej siły.

Polsko-ukraińskie konflikty na tle narodowym, podczas drugiej wojny światowej przeradzające się $\mathrm{w}$ masowe rzezie, wywarły trudne do zatarcia piętno na późniejszych stosunkach Polaków i Ukraińców. Z politycznego punktu widzenia te tragiczne wydarzenia zamykały wszakże pewną epokę: na „skrwawione ziemie" wkroczyła Armia Czerwona, granice Polski przesunięto na zachód, a Ukraina w całości znalazła się pod panowaniem sowieckim. Relacje polsko-ukraińskie przestały mieć aktualne znaczenie polityczne - w sferze polityki podstawową kwestią stało się, rzecz jasna, położenie Ukrainy w ZSRR. Tu zaś, jak się okazało w ostatnich latach, status Ukraińców nie zmienił się zasadniczo $\mathrm{w}$ porównaniu $\mathrm{z}$ sytuacją dziewiętnastowieczną. To jeden $\mathrm{z}$ aspektów szerszego zagadnienia: trwałości tego, co przedrewolucyjne, w warunkach systemu sowieckiego. Dziś widać, moim zdaniem wyraźnie, jak wiele z rosyjskiej tradycji przetrwało w ZSRR i zachowało swą żywotność w postsowieckiej Rosji - mimo niszczycielskich zamierzeń bolszewicko-stalinowskiego reżimu i rzeczywistych zniszczeń, jakie się dokonały. Nawiązując do tytułu znanego przed laty dzieła Jana Kucharzewskiego, można by powiedzieć: „od białego caratu do czerwonego - i z powrotem". Nie mamy tu bynajmniej do czynienia z jakimiś starymi, instrumentalnie wykorzystywanymi dekoracjami - to głęboko utrwalone struktury mentalne. W odniesieniu do Ukraińców owa trwałość rosyjskiej tradycji oznacza konsekwentne kultywowanie dziewiętnastowiecznego wyobrażenia „młodszych braci”, którzy winni posłuszeństwo narodowi „historycznemu".

Po rozpadzie ZSRR tego rodzaju przekonania zaczęły wchodzić w otwarty konflikt z ukraińskim pragnieniem emancypacji. Wydaje się, że jedyną realną szansę emancypacyjnego sukcesu dałoby kulturowe i polityczne zbliżenie do krajów zachodnich: wyrwanie się z kręgu „rosyjskiej tradycji”, karmiącej się słowianofilskimi fantazmatami, niechęcią do Zachodu i imperialnymi ambicjami. Włączanie się Ukrainy w krwiobieg zachodniego życia przyniosłoby perspek- 
tywę uzdrowienia gospodarki i podniesienia materialnego poziomu życia. Jednak największe znaczenie miałoby uzyskanie podmiotowości. Poczucie, że jest się podmiotem działania, stanowi podstawę wychodzenia $z$ peryferii. Kultura współczesnego Zachodu daje byłym „młodszym braciom” możliwość uzyskania takiego poczucia; nie można tego powiedzieć o kulturze imperialnej Rosji.

Nie są to tylko problemy wschodnioeuropejskie, choć polityka rosyjska nadaje im szczególny charakter. Kwestia peryferyjności ma wymiar ogólnoświatowy. Zachodni intelektualiści mogą zaprzeczać rzeczywistemu istnieniu peryferii, lecz inaczej sądzą rzesze imigrantów, którzy zmierzają tam, gdzie spodziewają się lepszego życia. W ostatnich kilkudziesięciu latach procesy globalizacyjne - w tym zwłaszcza niezwykłe nasilenie i przyspieszenie obiegu informacji - sprawiły, że o ile kiedyś z faktem bytowania na peryferii trudno było pogodzić się elitom, o tyle teraz stało się to problemem milionów. Z poczucia podrzędności wynikają niezwykle silne napięcia ideowe i polityczne. Imperialne dążenia „duszy rosyjskiej” są tylko jednym $z$ wielu wytworów frustrującego kontaktu z zachodnią nowoczesnością. Bliski Wschód pogrążony w głębokim, źle rokującym kryzysie, który destrukcyjnie wpływa na sąsiednie regiony; Ameryka Łacińska z wielką falą ruchów populistycznych - to inne najbardziej widoczne $\mathrm{w}$ mediach przejawy światowego zmagania się $\mathrm{z}$ peryferyjnością. Ten, kto dzisiejsze problemy Ukrainy chciałby uważać za czysto lokalne i ważne tylko dla sąsiadów, popełnia wielki błąd.

\section{BIBLIOGRAFIA}

Bauman Zygmunt, 2009, Nowoczesność i Zagłada, tłum. Tomasz Kunz, Wydawnictwo Literackie, Kraków.

Black Cyril E. (red.), 1976, Comparative Modernization: A Reader, Free Press, New York.

Chlebowczyk Józef, 1983, O prawie do bytu matych i młodych narodów: kwestia narodowa $i$ procesy narodotwórcze we wschodniej Europie Środkowej w dobie kapitalizmu (od schytku XVIII do poczattków $X X$ w.), Państwowe Wydawnictwo Naukowe, Warszawa.

Domański Henryk (red.), 2008, Inteligencja w Polsce: specjaliści, twórcy, klerkowie, klasa średnia, Wydawnictwo IFiS PAN, Warszawa.

Eisenstadt Shmuel N., 2009, Utopia i nowoczesność, tłum. Adam Ostolski, Oficyna Naukowa, Warszawa.

Jedlicki Jerzy, 2000, Świat zwyrodniaty: lęki i wyroki krytyków nowoczesności, Sic!, Warszawa.

Jedlicki Jerzy, 2002, Jakiej cywilizacji Polacy potrzebują: studia z dziejów idei i wyobraźni XIX wieku, W.A.B.-CiS, Warszawa.

Jedlicki Jerzy, 2010, Nasz kraj na peryferiach Europy, w: Maciej Koźmiński (red.), Cywilizacja europejska: eseje $i$ szkice z dziejów cywilizacji i dyplomacji, Wydawnictwo Instytutu Historii PAN, Warszawa.

Kołakowski Leszek, 1988, Główne nurty marksizmu: powstanie — rozwój — rozkład, Aneks, Londyn.

Kołakowski Leszek, 1990, Cywilizacja na ławie oskarżonych, Res Publica, Warszawa.

Nowak Andrzej, 2011, Imperiological Studies: A Polish Perspective, Wydawnictwo Towarzystwa Naukowego „Societas Vistulana”, Kraków.

Odpowiedzi na ankietę, 2013, „Kwartalnik Historyczny”, t. 120, nr 4.

Riabczuk Mykoła, 2014, Kolonializm inaczej. O przydatności metodologii postkolonialnej do badań nad Europa postkomunistyczna, tłum. Katarzyna Kotyńska, „Nowy Prometeusz”, nr 6. 
Rosdolsky Roman, 1964, Friedrich Engels und das Problem der "geschichtslosen Völker”. Die Nationalitätenfrage in der Revolution 1848-1849 im Lichte der „Neuen Rheinischen Zeitung”, „Archiv für Sozialgeschichte", t. 4, s. 87-282.

Sosnowska Anna, 2004, Zrozumieć zacofanie: spory historyków o Europę Wschodnia (1947-1994), Trio, Warszawa.

Szamuely Tibor, 1974, The Russian Tradition, Robert Conquest, Secker \& Warburg, London.

Szporluk Roman, 2003, Imperium, komunizm i narody. Wybór esejów, wstęp i red. Andrzej Nowak, tłum. Szymon Czarnik, Andrzej Nowak, Arcana, Kraków.

Tipps Dean C., 1973, Modernization Theory and the Comparative Study of Societies: A Critical Perspective, "Comparative Studies in Society and History", t. 15, nr 2, s. 199-226.

Veǐdle Vladimir, 1949, La Russie absente et presente, Gallimard, Paris.

Walicki Andrzej, 1964, W kręgu konserwatywnej utopii: struktura i przemiany rosyjskiego stowianofilstwa, Państwowe Wydawnictwo Naukowe, Warszawa.

Walicki Andrzej, 1996, Marksizm i skok do królestwa wolności: dzieje komunistycznej utopii, Wydawnictwo Naukowe PWN, Warszawa.

Wapiński Roman, 1994, Polska i mate ojczyzny Polaków. Z dziejów ksztattowania się świadomości narodowej w XIX $i$ XX wieku, Ossolineum, Wrocław.

Weeks Theodore R., 1996, Nation and State in Late Imperial Russia: Nationalism and Russification on the Western Frontier, 1863-1914, Northern Illinois University Press, De Kalb, Illinois.

Wehler Hans-Ulrich, 1975, Modernisierungstheorie und Geschichte, Vandenhoeck \& Ruprecht, Göttingen.

Wolff Larry, 1994, Inventing Eastern Europe: The Map of Civilization on the Mind of the Enlightenment, Stanford University Press, Stanford.

\section{UKRAINE, RUSSIA, AND THE QUESTION OF PERIPHERALITY}

\section{Summary}

In this essay, the author addresses the question of Ukraine's and Russia's relations with the West in the modern and contemporary era. He believes that the revolution in Ukraine in 2013/2014 signifies a successive stage in Ukraine's emancipation and modernization, which began with the emergence of a separate nation on its territory in the $19^{\text {th }}$ century. The author is in favor of the further use of such conceptual categories as the 'centre', the 'periphery', and 'modernization'. He thinks they still permit the description of the real developmental distance between different parts of the world and the analysis of strategies aimed at diminishing that distance. In his opinion, Ukraine's present chance for modernization is unambiguously connected with its choice of the 'western' road of development. He interprets the Russian attempt to counteract this choice by force as an expression of the disappointment experienced by the elite of the former empire. In essence, it is a sign that Russia is remaining in a peripheral situation in regard to the West, which is 'escaping' it.

\section{Key words/słowa kluczowe}

centrum i peryferie / centre and periphery, teorie modernizacji / modernization theories, studia postkolonialne / postcolonial studies, rosyjskie słowianofilstwo / Russian slavophilism 